\title{
Involvement of Women in Sustainable Aquacultural Development of Nigeria
}

\author{
Bolarinwa Josef Bamidele* \\ Department of Fisheries technology, Lagos State Polytechnic, Nigeria
}

Submission: March 13, 2017; Published: March 21, 2017

*Corresponding author: Bolarinwa Josef Bamidele, Department of Fisheries technology, Lagos State Polytechnic, P.MB 21606, Ikeja, Lagos, Nigeria, Email: bolabolero@yahoo.com; delebolero2015@gmail.com

\begin{abstract}
Despite the immense fish biodiversity of Nigeria, there is a still a wide gap between supply and demand of fish, thus leading to high prices of fish products which makes them unaffordable to the common man. Of recent, though women are becoming increasingly involved in aquacultural practices especially homestead culture of African catfish Clarias gariepinus, the sector (especially artisanal fisheries) is still male-dominated. The age-long traditional and marginal role of women as marketers and processors and financiers of fish need to change to direct fish producers for sustainable development in the sector. This paper highlights the factors affecting effective participation of women in direct fish production in Nigeria and calls for increased access to credits, inputs and land to potential women investors. Various constraints faced by women in fisheries livelihoods include restricted access to credit, inadequacy of education, dearth of infrastructural facilities, low participation in decision-making due to apathy for women in African setting, land tenure system, traditional beliefs and taboos, lack of access to information through extension services, poor cooperative society formations. The author emphasized the need for attitudinal changes in a patrilineal society like Nigeria by the men folks towards participation of women in the male-dominated profession like fisheries. Women should be regarded as equal partners in sustainable development of the fisheries sector. The author advocated culture fisheries for Nigerian women because of the less risky, lesslaborious and more environment-friendly nature of fish farming.
\end{abstract}

\section{Introduction}

Nigeria has a coastal line of $900 \mathrm{~km}$ bordering the Gulf of Guinea and a continental shelf area of 7,934sq km. In 1978, Nigeria declared a 200 nautical miles Exclusive Economic Zone (EEZ) which gave an area of $210,900 \mathrm{~km}^{2}$ over which she has propertial rights for the purpose of exploiting, conserving and managing her fisheries resources. Nigeria is one of the few countries that can boast of 230 billion cubic meters of water making it one of the richest countries for aquacultural development and fish marketing. Despite these rich and varied ichthyofauna resources of Nigeria, there is still a large shortfall between supply and demand for fish.

According to report from Federal Department of Fisheries (2010), the total fish production was estimated at 600,000 metric tonnes per annum while importation was estimated at about 700,000 tonnes. Projected demand for fish was about 2.6 million tonnes a shortfall of about 1.3 million tonnes.

Adesina [1] reported that unlocking the potentials of the fisheries value chain is crucial to diversification of the nation's economy through huge investment by the government. Wealth can be created by practicing aquaculture as a business rather than a developmental programme. It is capable of providing 5.5 million jobs by 2020 [2].

African women have long been associated with agriculture; they have the greatest female participation in agriculture of all regions in the World. Africa is considered the region of female farming per excellence [3]. About $85 \%$ of rural women are involved in production and handling of up to $80 \%$ of the food eaten by the families [4,5]. Akerele [6] asserts that Liberian women play a vital role in fish marketing and processing, distribution and as financiers using cooperative societies in most fishing communities. Women in Bangladesh supplement income by making nets and fish farming according to Agbontale \& Eyo [7].

Odili etal. [3] reported the downplay of the importance of women in Senegalese Fisheries industry as processors, distributors by the male fisher folks because of the latter higher level of education and access to credit. Williams (2006) also reported that majority of the female fisher folks are illiterates, hence their marginal contribution to fisheries. However, despite their pivotal role in food security, they have remained quite invisible and their roles under reported and documented. The major obstacles of African development cannot 
be overcome without full participation of women. Any society that is seriously committed to raising the standard of living needs to consider women, not as marginal to development but as essential human resources according to [8]. Past government programs on women empowerment like' Better Life for Rural Women in Nigeria', Beijing Convention and Action 26 of the Global Biodiversity Strategy International Union For The Conservation of Nature and Natural resources) attest to the importance of women as partners in progress [9].

However, the fact that there exists little information about women and their existing roles in the fisheries sector is something that cannot be denied in Nigeria, hence the need for this present study.

\section{Roles of Women in Fisheries}

Women are less involved in fish trawling at sea and even artisanal fisheries in lakes because of its inherent dangers, long period of fishing voyage and their dominant role in household activities [4]. Research findings have indicated that women have traditionally been occupied in pre and post- harvest processing of fish products, distribution and marketing of fish and other income- generating non fisheries activities $[5,10]$. Women perform the functions of auctioneers, retailers, fish vendors and dealers in export [8].

\section{Feed Formulators}

Nwabeze [11] reported that women are more involved in feed formulation and daily maintenance in homestead ponds. In Nigeria, a lot of women (most of whom are members of Lagos State Catfish Farmers Association and Fisheries Society of Nigeria) are involved in homestead fish rearing of African catfish (Clarias gariepinus) [12].

\section{Fish preservation, storage, marketing and packaging}

Smoking in artisanal fisheries is predominantly done by women as confirmed by various workers apart from post-harvest ice storage, distribution, packaging and marketing $[7,5]$.

\section{Direct fishing}

Williams (2006) reported the involvement of women in direct fishing using small scale fishing gears like pots, baskets, traps, fences, barriers and shelter, hooks and line. Bolarinwa [5] also reported the active involvement of On do State coastal waters in a catching fish. Women are also involved in oysters harvesting in the brackish water of Buguma in Niger Delta using paddled canoes.

\section{Sorting and transportation}

Fish are transported to market centres through open system using open carriers with or without artificial aeration [13].

\section{Constraints Faced by Women}

\section{These include the following}

Low participation in decision making due to gender inequality: In most patrilineal societies like Nigeria, women are only to be seen and not heard, they are therefore not usually consulted before taking decisions. Because of gender inequality in some communities in Nigeria, the efforts of women in fisheries are not recognized, no matter how hard they try because they are regarded as minorities. There is therefore a need for attitudinal changes.

\section{Lack of basic education}

This apathy towards women as equal partners in progress also contributed to the higher illiteracy level among female fisher folks $[13,14]$. The age-old belief that women are weaker and meant only for procreation and culinary function should stop in the new millennium.

\section{Lack of land ownership}

Nigeria being a patrilineal society unlike Ghana and Rwanda, rural women are often disadvantaged in terms of land accessibility. Only in very few States can women own land. The land tenure system does not favour women. Changing the land tenure system could greatly affect the status of women, thus making them to go into fish farming.

\section{Dearth of social and infrastructural facilities}

Presence of infrastructural facilities like power, municipal water, good roads, health centres in the rural fishing communities could stimulate rural income; reduce fishing efforts and subsequently sustainability and development $[15,16]$.

\section{Restricted access to credit}

This is a major handicap to effective participation of women in fisheries. Generally fisheries is considered a 'no go area' by most formal agrilending institutions in Nigeria as confirmed by many workers $[17,18]$, The low literacy level of women has always been a constraint to accessing funds from formalized sources. They have to depend on credit from friends and thrift to purchase fish inputs such as nets, boats, fertilizers, feeds etc at subsidized rates. Cooperative society formation was recommended to facilitate better access to inputs [19]. The bureaucratic bottlenecks like collateral securities have further aggravated the situation, hence the need to train the women.

Past workers have confirmed women as being better managers of funds than their male counterparts Women repay loans faster than their male counterparts (most of whom divert loans to ostentatious transactions [20-26].

\section{Inadequate dissemination of information through extension services/change agents}

Because of the usually bad terrain in the fishing communities, there is generally poor access to extensionists/change agents. The creeks are not accessible to most transportation means. Past workers like Wara et al. [26], Adeleke [3].

\section{Conclusion}

It is high time women are considered as equal partners in sustainable fisheries development in Nigeria. Women should never be seen as invincible but should be recognized as partners 
in progress towards sustainable fisheries development. They should be more involved in direct production especially in the area of culture fisheries which is more environment-friendly and less risky than capture fisheries. Women should be encouraged through introduction of specially designed programmes.

Fishing inputs should be made available to all irrespective of sex. They should be encouraged to form cooperative association that would facilitate cheaper and better access to credit and inputs at concessionary rates.

Policy makers should adopt the 'Bottom-Up approach' which is tailored at the needs of rural women/fisher folks. They should be consulted during policy formulation because they are the stake holders. There is a need for gender-sensitiveness in Nigeria's move to sustainable fisheries development

The government should create a condutive enabling environment such as provision of social amenities in the fishing communities. Despite their being the major contributor to the domestic fish output, the coastal communities lack basic infrastructural facilities like power, post- harvest storage structures, health centres, municipal waters and so on.

\section{References}

1. Adesina A (2012) The Role of Fisheries in the National Agriculture Transformation Agenda. Paper presented at the $27^{\text {th }}$ Annual Conference of Fisheries Society of Nigeria held in Yenagoa, Bayelsa State, Nigeria.

2. Balogun AM (2015) The Fisheries sub-sector in a declining Oil-based Economy: Paradigm shift for Economic Diversification and Employment generation. Keynote address at the $30^{\text {th }}$ Annual Conference of Fisheries Society of Nigeria, Nigeria, p. 12-15.

3. Odili OE, Nwabeze GO, Tafida AA, Chilaka (2012) Contribution of women to Fisheries Development in Nigeria: A review. $27^{\text {th }}$ Annual Conference of Fisheries Society of Nigeria Proceedings, Nigeria, pp. 435-437.

4. Akosua (1998) Women and Food security: The Opportunity for Africa Development. Journal of Science and Development 2(3): 112-113.

5. Bolarinwa JB (2015) The ichthyofauna Resources of The Coastal waters of Ondo State, Nigeria. Ph.D Thesis, Federal University of Technology, Akure, Nigeria, pp. 95-140.

6. Akerele O (1979) Women in Fishing Industry in Liberia: Measures of women's participation. Econs Commission for Africa.

7. Agbontale AO, Eyo AA (2005) Assessment of women's contribution to fishing activities around Lake Kainji. Annual Conference of Fisheries Society of Nigeria Proceedings,Nigeria, pp. 435-437.

8. Bolarinwa JB (2014) Role of Extension Services and Public Relations in Nigerian Fisheries Industry. International Journal of Agricultural Research 9(7): 325-330.

9. FDF (2010) Fisheries Statistics of Nigeria. ( ${ }^{\text {th }}$ edn), Federal Department of Fisheries, Abuja, Nigeria.
10. Adeleke ML (2014) Adaptation of the artisanal Fisher folks to Climate change in the coastal region of Ondo State. Department of Agricultural Economics, Federal University of Technology, Akure, Nigeria, p. 1-44.

11. Nwabueze AA (2010) The role of women in sustainable aquacultural development in Delta state. Journal of Sustainable Development in Africa 12(5): 23-25.

12. Adewumi AA, Olaleye VF (2011) Catfish culture in Nigeria: Progress, Prospects and Problems. African Journal of Agricultural Research 6(6): 297-306.

13. Ovie SO, Ovie SI (2010) Aquaculture in Focus. Remi-Thomas Publisher, Ilorin, Nigeria, pp. 65-67.

14. Cliffe PT, Akinrotimi OA (2015) The Role of Women in Fisheries activities in Some Coastal communities of Rivers State. International Journal of Agricultural Research 10: 24-32.

15. Elliot M (2002) The role of women on fisheries (Internet).

16. Omitoyin SA, Fregene BT (2008) Sources and Impact of microcredit on the productivity of artisanal fisher folks in Lagos Lagoon. Proceedings of Fisheries Society of Nigeria, Nigeria, pp. 103.

17. Abass MA, Kumolu-Johnson CA, Fakoya KA (2010) A biotechnical assessment of the artisanal Purse seine fishery at Orimedu coastal village in Lagos State, Nigeria. Nigerian Journal of Fisheries 7: 1.

18. Olaoye OJ, George FOA, Abdul WO, Adelaja OA, Ashley-Dejo SS, et al. (2012) Profitability and viability of fish farming enterprises using Government credit Agency Loan in Ogun State, Nigeria. Nigerian Journal of Fisheries 9(1): 460-463.

19. United Nations Development Program (UNDP) (1998) Baseline Survey of Agriculture, Rural Development, Health and Mass Literacy of States of Nigeria. conducted by Gothards-IHLS Consortium, Nigeria, pp. 1-23.

20. Wara A, Nwabeze GO, Tafida AA, Abubakar SM (2007) Women in Fisheries: A case study of the Kainji Lake Basin, Nigeria. Proceedings of the Fisheries Society of Nigeria, p. 66- 67.

21. Adebayo 0, Pitan OO (2001) Role of women in marketing of frozen fish in Lagos state. Annual Conference of Fisheries Society of Nigeria Proceedings, pp. 435-437.

22. Agbelege 00 (2007) Constraints associated with fishing activities in Lake Chad. Annual Proceedings of Fisheries Society of Nigeria, pp. 165170.

23. Alamu SO (1998) Women in artisanal fish production: Kainji and Jebba Lake Basin. NIFFRI Annual Report, New Bussa, Nigeria, pp. 46-61.

24. Babale UG (2003) Role and Contributions of the Nigerian Agricultural Cooperative and Rural Development Bank Ltd to the development of the Fisheries Industry in Nigeria. Proceedings of Annual Conference of Fisheries Society of Nigeria, pp. 80-82.

25. FAO (2012) Strategies for Sustainable Animal Agriculture in Developing countries. Proceedings of the FAO Expert Consultation, Animal Production and Health Paper 107

26. Nwabueze GO, Eric AP, Ifejika PI, Ayanda JO, Tafida AA (2007) Strengthening Fisheries extension under a unified Agricultural Extension System. (UAES) Proceeding of Fisheries Society of Nigeria. 
This work is licensed under Creative Commons Attribution 4.0 License

DOI: 10.19080/ARTOAJ.2017.05.555653
Your next submission with Juniper Publishers will reach you the below assets

- Quality Editorial service

- Swift Peer Review

- Reprints availability

- E-prints Service

- Manuscript Podcast for convenient understanding

- Global attainment for your research

- Manuscript accessibility in different formats ( Pdf, E-pub, Full Text, Audio)

- Unceasing customer service

Track the below URL for one-step submission https://juniperpublishers.com/online-submission.php 